\title{
The Collective Learning Community for Climate Change Adaptation in Mauche Ward of Njoro Sub-county, Kenya
}

\author{
Taiy Rael Jepkemei ${ }^{1, *}$, Onyango Christpher ${ }^{2}$, Nkurumwa Agnes $^{2}$, Ngetich Kibet ${ }^{3}$, Birech Rhoda ${ }^{4}$, \\ Maling'a Joyce ${ }^{5}$, Ooro Patrick ${ }^{5}$ \\ ${ }^{1}$ Ministry of Agriculture, Livestock and Fisheries, Agricultural Sector Development Support Programme Uasin Gishu County, Kenya \\ ${ }^{2}$ Department of Agricultural Education and Extension, Egerton University, Kenya \\ ${ }^{3}$ Department of Sociology and Anthropology, Egerton University, Kenya \\ ${ }^{4}$ Department of Crops, Horticulture and Soil Chemistry, Egerton University, Kenya \\ ${ }^{5}$ Kenya Agricultural and Livestock Research Organization (KALRO), Kenya
}

Copyright $\mathrm{O} 2017$ by authors, all rights reserved. Authors agree that this article remains permanently open access under the terms of the Creative Commons Attribution License 4.0 International License

\begin{abstract}
Participatory innovation in agriculture is key in enhancing food security in Sub-Sahara Africa. The Collective Learning Community (CLC) concept entails bringing people together for shared learning, discovery and generation of knowledge. It enhances formation of networks to promote continuous interaction and communication. Farmers in Mauche Ward of Njoro Sub-County depended on rain fed agriculture vulnerable to rainfall variability and the negative effects of climate change. Linkages needed for innovation to support growth and development in the potato value chain were generally weak; hence inadequate clean potato seed and lack of market access were major challenges to potato production A Collective Learning Community (CLC) comprising of farmers and other potato value chain actors was established to exchange knowledge and collaboratively innovate for climate change adaptation. The Net-Map toolbox was used to assess the links between actors based on exchange of information, sharing of resources and influence. This enabled the CLC to clarify roles and power relations among the actors; and to identify weak points in the network that needed addressing. Membership to the CLC enabled farmers to access climate change adaptation technologies, clean potato seed and negotiate for a better potato price. The study recommends collective learning, positive selection for clean seed production, group marketing of potato and involving of local leadership in climate change adaptation initiatives for sustainability.
\end{abstract}

Keywords Adaptation, Climate Change, Collective Learning, Potato, Smallholder

\section{Introduction}

The effect of climate change on food security is exhibited through its negative impacts on food production worldwide, as noted by Ospina \& Heeks [1]. Climate change adaptive capacity and resilience may be enhanced through household practices such as land and water management, use of hardy and improved seeds, shorter-cycle and drought-tolerant varieties, diversifying the varieties of crops planted and planting more than one crop at the same time (Kristjanson et al. [2], International Resources Group[3]).

Although the Kenyan agricultural sector supports the livelihood of over 70 percent of the rural population according to Government of Kenya [4], it is mainly rain fed and hence vulnerable to climate-induced risk and uncertainty. Ojwang et al. [5] observed that many of the initiatives intended to strengthen the climate change adaptive capacity of communities in Kenya have failed partly due to lack of awareness of their availability. In recognition of this, Smallholder Farmer Strategies to Cope with Climate Change (SMACC) project was initiated by Egerton University in collaboration with University of Natural Resources and Life Sciences in Austria, University of Hohenheim in Germany, Bahar Dar University in Ethiopia and two agricultural research institutions: Kenya Agricultural and Livestock Research Organization (KALRO) Njoro in Kenya and Amhara Region Agricultural Research Institute (ARARI) in Ethiopia. The aim of the project was to provide field-to-market strategies for production intensification of selected key crops that are regionally adapted to help Sub-Saharan Africa cope with climate change. The overall objective of the project was to encourage actors who depended on rural livelihoods to cope with climate change through production intensification in a cyclical process of collective learning across a systemic innovation value chain.

Collective learning processes provide a basis for the exchange and dissemination of knowledge as well as sharing and application of climate change adaptation innovations (Freyer et al. [6]). According to Lang et al. [7], a Collective 
Learning Community (CLC) is a trans-disciplinary approach to tackle fundamental societal challenges. It entails formation of information-sharing platforms that enable different actors to come together and analyze shared constraints, promote dialogue, access new technologies, collaborate, engage in joint innovation and investment (International potato centre [8]). New knowledge is generated and integrated into the existing body of scientific knowledge. It becomes transferable and applicable to other cases and other problem constellations (Lang et al. [7]. The CLC concept entails bringing people together in an innovation platform for shared learning, discovery and generation of knowledge. It enhances formation of networks to promote continuous interaction and communication.

Freyer et al. [6] explain that the CLC approach is built on three pillars:

Pillar 1: A network, which involves all relevant actors and organizations in the project area, is seen as the logistic center of the project. The network serves to identify the needs, expectations and objectives of each partner, as well as their resources and capacities to contribute to innovation processes. It provides a basis for the exchange and dissemination of knowledge; for initiating common iterative learning processes; as well as for the development, sharing and application of innovations (technology transfer). The network also provides a social component, which serves for strengthening the collaboration between all partners.

Pillar 2: A broad knowledge base gathered from local, regional, national, and international sources, which will be shared with, reflected upon, and rethought by all the involved actors.

Pillar 3: Dissemination of knowledge, initiation and application of innovations at the different levels and capacity building. Knowledge dissemination and generation of activities are done on the basis of existing knowledge, research findings and a process of critical reflection aided by ongoing discussions with all members of the CLC-network. Figure 1 illustrates the CLC concept for climate change adaptation.

Integrating climate change adaptation strategies in potato production is better achieved through participatory innovation. As noted by Nederlof et al. [10], participatory innovation in agriculture provides an important contribution towards improving agricultural development and food security in Africa. Krasny \& Lee[11] added that farmers and other actors become experts instead of simply users or receivers of information from specialists. Through Participatory Action Research (PAR),potato value chain stakeholders in a CLC engaged in collective inquiry and experimentation to test, select and integrate $\mathrm{CC}$ adaptation strategies relevant for smallholder potato production. Thus, in order to secure the best possible climate change adaptation strategies, this research started at the farm inputs level and followed the potato value chain via households to the local and regional levels. Lang et al. [7] asserted that the value chain approach engages stakeholders in an action-oriented method that acknowledges the linkages in the chain with a flexible implementation as well as creating ownership for problems and solution options.

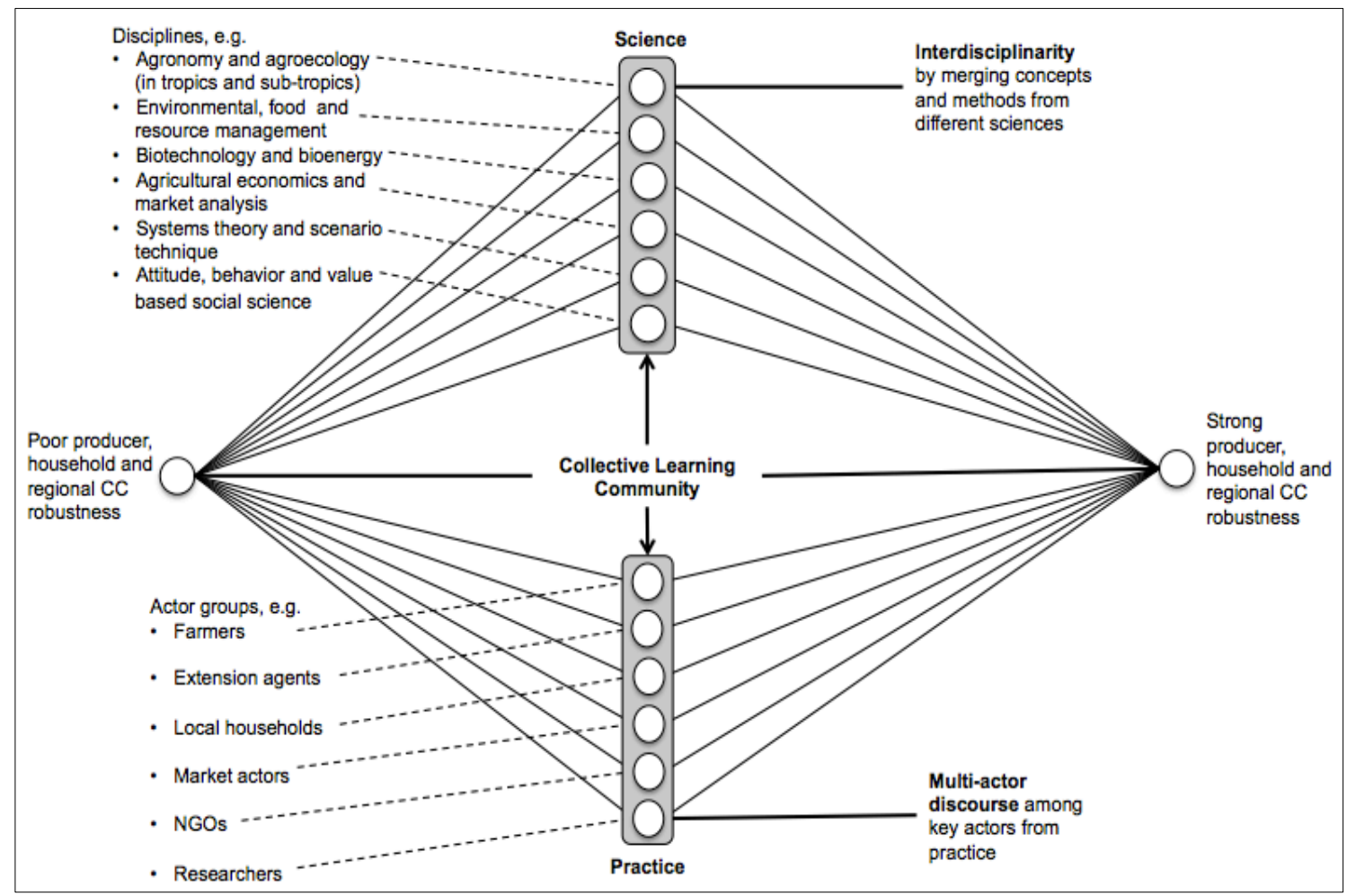

Figure 1. The Collective Learning Community concept: (Source: Freyer et al. [6], adapted from Scholz [9]. 


\section{Materials and Methods}

\subsection{The Study Area}

The study was carried out in August 2013 to September 2016 in Mauche Ward of Njoro Sub-County, Kenya. According to Government of Kenya [12], Mauche lies in the
Mau escarpment and covers an area of 166 square kilometers at an altitude range of $2100-2800 \mathrm{~m}$ above sea level and receives an annual rainfall of $1600-2200 \mathrm{~mm}$. The rainfall pattern is bimodal with the long rains received in March to August and short rains in October to December. The Njoro rainfall data is presented in Figure 2.

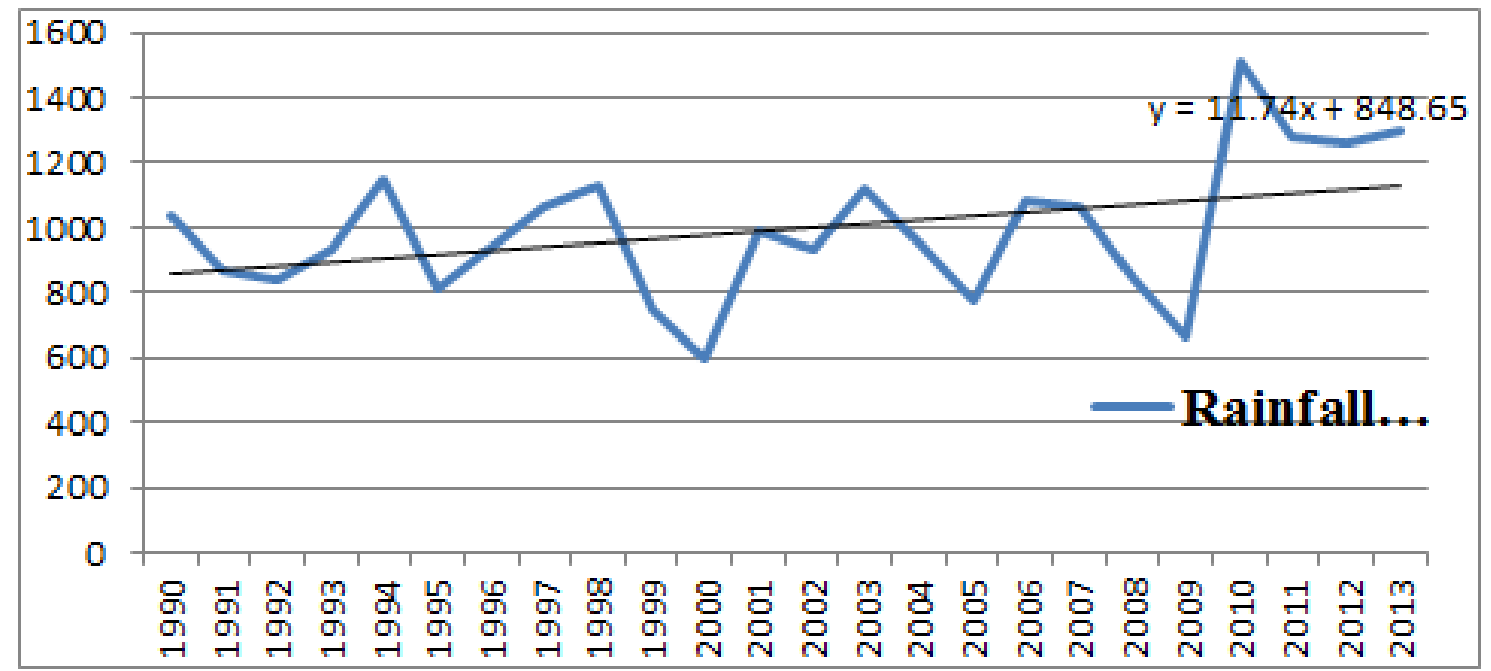

Figure 2. Rainfall data for Njoro: 1990-2013 - Source, KALRO Njoro

Table 1. Matrix of potato value chain stakeholders in Mauche Ward

\begin{tabular}{|c|c|c|c|c|}
\hline Stakeholder & Attribute & Interests & Resources & Impacts \\
\hline $\begin{array}{c}\text { Chomosa Farmers' Self } \\
\text { Help Group }\end{array}$ & $\begin{array}{l}\text { Smallholder potato } \\
\text { farmers, primary } \\
\text { decision makers } \\
\end{array}$ & $\begin{array}{l}\text { Primary producers of } \\
\text { potatoes }\end{array}$ & $\begin{array}{c}\text { Land } \\
\text { Labour } \\
\text { Farm inputs } \\
\end{array}$ & $\begin{array}{l}\text { Implementation of climate change } \\
\text { adaptation strategies, dissemination } \\
\text { and potato seed supply. }\end{array}$ \\
\hline Egerton University & $\begin{array}{l}\text { Primary decision } \\
\text { maker, project } \\
\text { coordinator }\end{array}$ & $\begin{array}{c}\text { Agricultural training, } \\
\text { technology generation and } \\
\text { dissemination }\end{array}$ & $\begin{array}{l}\text { Technical Capacity, } \\
\text { financial input. }\end{array}$ & $\begin{array}{l}\text { Funding implementation of the } \\
\text { interventions, monitoring and } \\
\text { evaluation }\end{array}$ \\
\hline KALRO Njoro & Main partner & $\begin{array}{l}\text { Agriculture and Livestock } \\
\text { research }\end{array}$ & Technical capacity & $\begin{array}{l}\text { Testing of climate change } \\
\text { adaptation technologies in the } \\
\text { Mother and Baby trial sites }\end{array}$ \\
\hline $\begin{array}{l}\text { Department of } \\
\text { Agriculture }\end{array}$ & Effective local partner & Extension service provider & $\begin{array}{l}\text { Technical capacity, } \\
\text { data source }\end{array}$ & $\begin{array}{l}\text { Dissemination of climate change } \\
\text { adaptation strategies, co-funding of } \\
\text { the interventions. }\end{array}$ \\
\hline $\begin{array}{l}\text { Local Leaders (Chief, } \\
\text { Member of County } \\
\text { Assembly, Mauche) }\end{array}$ & $\begin{array}{l}\text { Primary decision } \\
\text { makers and facilitators }\end{array}$ & $\begin{array}{l}\text { Community mobilization } \\
\text { and security }\end{array}$ & Law enforcement & $\begin{array}{l}\text { Provision of an enabling } \\
\text { environment for project } \\
\text { implementation }\end{array}$ \\
\hline $\begin{array}{l}\text { Faith-based organization } \\
\text { (African Gospel Church) }\end{array}$ & Local partner & $\begin{array}{l}\text { Religious and social welfare } \\
\text { of the community }\end{array}$ & Social Capital & $\begin{array}{l}\text { Community mobilization for } \\
\text { climate change adaptation }\end{array}$ \\
\hline $\begin{array}{c}\text { Agricultural } \\
\text { Development } \\
\text { Corporation, Molo } \\
\end{array}$ & Facilitator & Multiplier of potato seed & $\begin{array}{l}\text { Potato seed, technical } \\
\text { input }\end{array}$ & Supply of certified potato seed \\
\hline $\begin{array}{c}\text { Agricultural Technology } \\
\text { Development Centre, } \\
\text { Nakuru } \\
\end{array}$ & Facilitator & $\begin{array}{c}\text { Fabrication of farm } \\
\text { implements, storage and } \\
\text { value addition equipment }\end{array}$ & Technical capacity & $\begin{array}{l}\text { Supply of climate change } \\
\text { adaptation implements }\end{array}$ \\
\hline Farm input suppliers & Facilitators & Sale of assorted farm inputs & Farm inputs & $\begin{array}{l}\text { Supply of appropriate } \\
\text { agro-chemicals to potato farmers }\end{array}$ \\
\hline Potato traders & Facilitators & $\begin{array}{c}\text { Purchase and sale of } \\
\text { potatoes }\end{array}$ & $\begin{array}{l}\text { Cash, market } \\
\text { premises }\end{array}$ & $\begin{array}{l}\text { Provide a market for potatoes, link } \\
\text { producers to consumers. }\end{array}$ \\
\hline Potato transporters & Facilitators & $\begin{array}{l}\text { Transport potatoes from } \\
\text { farmers to the markets }\end{array}$ & Means of transport & $\begin{array}{c}\text { Enable potato farmers to access the } \\
\text { market }\end{array}$ \\
\hline $\begin{array}{l}\text { Processor (Njoro } \\
\text { Canning Factory) }\end{array}$ & Facilitator & $\begin{array}{l}\text { Value addition to } \\
\text { agricultural produce }\end{array}$ & $\begin{array}{c}\text { Processing facility } \\
\text { for local agricultural } \\
\text { produce }\end{array}$ & $\begin{array}{l}\text { To contract farmers for supply of } \\
\text { potatoes to the factory. }\end{array}$ \\
\hline
\end{tabular}


Agro-ecological zones are Upper Highlands and Lower Highlands. Mauche has a population of 25,088 comprising of 4994 households and 5590 farm families. The livelihoods of the people in the study area depend on farming of crops such as maize, potato, beans and vegetables and keeping of livestock notably cattle, sheep and local chicken.

\subsection{Data Collection Methods}

This study carried out stakeholder analysis to establish the main actors in the potato value chain in Mauche. Based on that, purposive sampling was employed to select 50 stakeholders to form a Collective Learning Community (CLC) comprising of farmers and representatives of key relevant institutions in the study area. The Net-Map toolbox was employed to assess the actor linkages. Multi-criteria analysis was carried out to prioritize and select climate change adaptation strategies from the options tested at KALRO Njoro, to be implemented on 3 baby trial project sites in Mauche. These strategies were implemented collaboratively through Action Research by the CLC. Capacity building of the CLC was done through trainings, field days, tours, workshops and participation in the management of the baby trials. Monitoring and Evaluation of the research process was done through farm visits and observations, focus group discussions, farmer interviews and brain storming in workshops. Qualitative data analysis was done using Thematic Content Analysis.

\section{Results and Discussion}

\subsection{Stakeholder Analysis}

Stakeholder analysis was done to determine the key actors considered to have a significant influence on the success of the climate change adaptation intervention in smallholder potato production in Mauche. Golder [13] asserts that stakeholder analysis helps identify the interests of all stakeholders who may affect or be affected by a project; potential conflicts or risks that could jeopardize the initiative; opportunities and relationships that could be built by various participating groups at different stages and strategies for stakeholder engagement. Table 1 provides a matrix of key potato value chain actors in Mauche Ward.

\subsection{Constituting the Collective Learning Community membership}

Based on the stakeholder analysis, a Collective Learning Community for climate change adaptation comprising of 50 members was formed in Mauche. Purposive sampling was applied to select a community based organization (Chomosa farmer group with 31 members), a representative of agricultural institutions (Egerton University); potato seed multiplier (ADC Molo); faith based organization (African Gospel Church); processor (Njoro canning factory); Researcher (KALRO Njoro); extension service provider (County Department of Agriculture); local Administration (Chief Mauche Location); department of social services
(Mauche Community Development Assistant); a Non-Governmental Organization (East African Grain Council); Four officials of 2 other potato farmer groups (Ogiilgei Self Help Group and Kaplelach Youth Group). Simple random sampling was used to select 2 agro-input suppliers, 2 potato traders and 2 transporters to participate in the CLC.

\subsection{Identification of a Leading Team}

Elections were democratically carried out to identify CLC officials after which roles were spelt out. The Chairperson's role was to convene and chair meetings as well as take charge in resource mobilization. The secretary was to be a custodian of records, minutes and all project documents. The treasurer was to be in charge of finances. The Mauche Ward Agricultural Extension Officer was coopted into the CLC committee to spearhead linkages with government, stakeholders and service providers. The CLC Committee's ultimate role was to ensure sustainable adaptation of climate change adaptation strategies.

\subsection{Assessing Linkages between Actors}

The Net-Map toolbox was used to assess the links between the actors based on exchange of information, sharing of resources and influence. As explained by Schiffer [14], the Net-Map toolbox is a participatory tool that aids a target group of people to clarify, converse and identify situations that can be improved where there are numerous stakeholders and actors that have the ability to impact the outcome. It is a social analysis tool that uses discussion and mapping to help people understand, visualize and improve situations in which many different actors influence results.

The Net-Map toolbox presents the structures of a situation; the actors and what their power relations are, the influence different actors hold, links between the actors, and the objectives of the various actors. It innovates a process that enhances the way in which people work together to reach a common goal. Schiffer [14] further notes that the Net-Map toolbox aids in comprehension of a complex system and issues through visualizing the situation. The Net-Map toolbox enabled the CLC to clarify the roles and power relations among the actors; and also to identify strong and weak points in the network that needed addressing.

Members of the CLC who participated in producing the Net-map tool box included farmer representatives, researchers, extension service providers, processors, traders, transporters, input suppliers, area chief, a pastor representing several churches in the area. Links between actors were demonstrated using arrows. Linking the actors clarifies the roles within the organization and which actors gave and received commands, advice, information and money. These links were demonstrated through the use of different colored arrows with red representing exchange of information, black commands, green money and blue advice.

Actors were specifically asked about their perception on the SMACC project's aim of enabling farmers to cope with climate change through potato production intensification. It 
was essential to find out which actors supported the goal of the project. The actors were ranked according to who had more influence on the success of the project on a scale of 1-10. A higher scale represented higher influence.A Netmap of stakeholder linkages drawn by participants on a flip chart with felt pens is presented in Plate 1.

The Net-Map of stakeholders was re- created in word as a digital processed net-map ( Figure 3) showing the actors involved, the links between different actors with regard to exchange of information, advice, money, level of command and influence. It provided a working structure that could be modified by recommendations and changes over time.

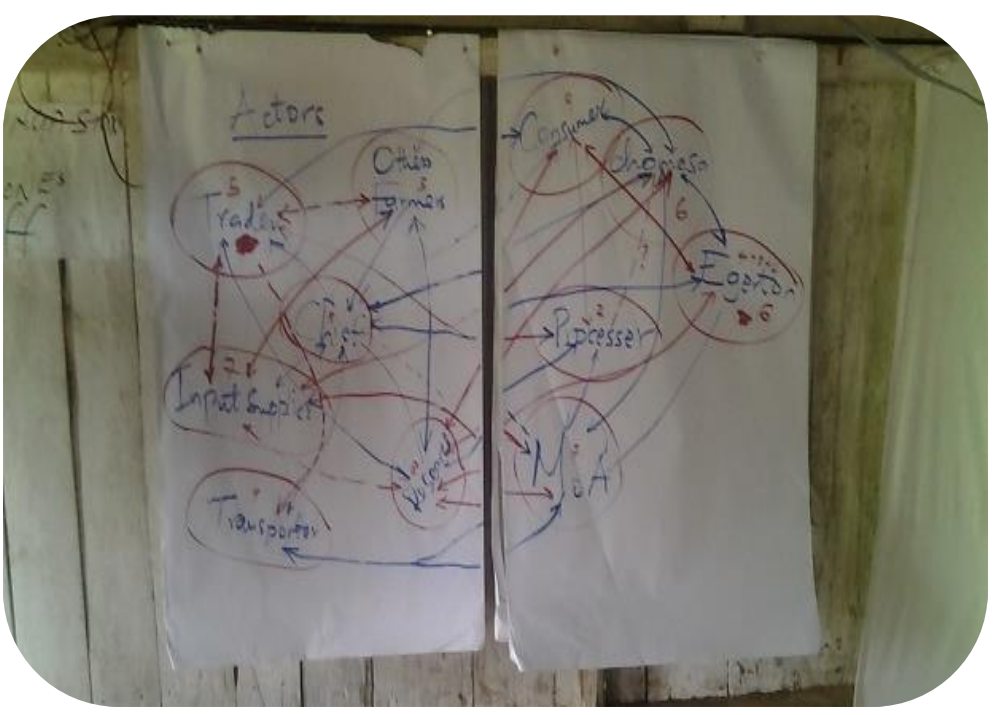

Plate 1. A Net-Map of stakeholder linkages in Mauche

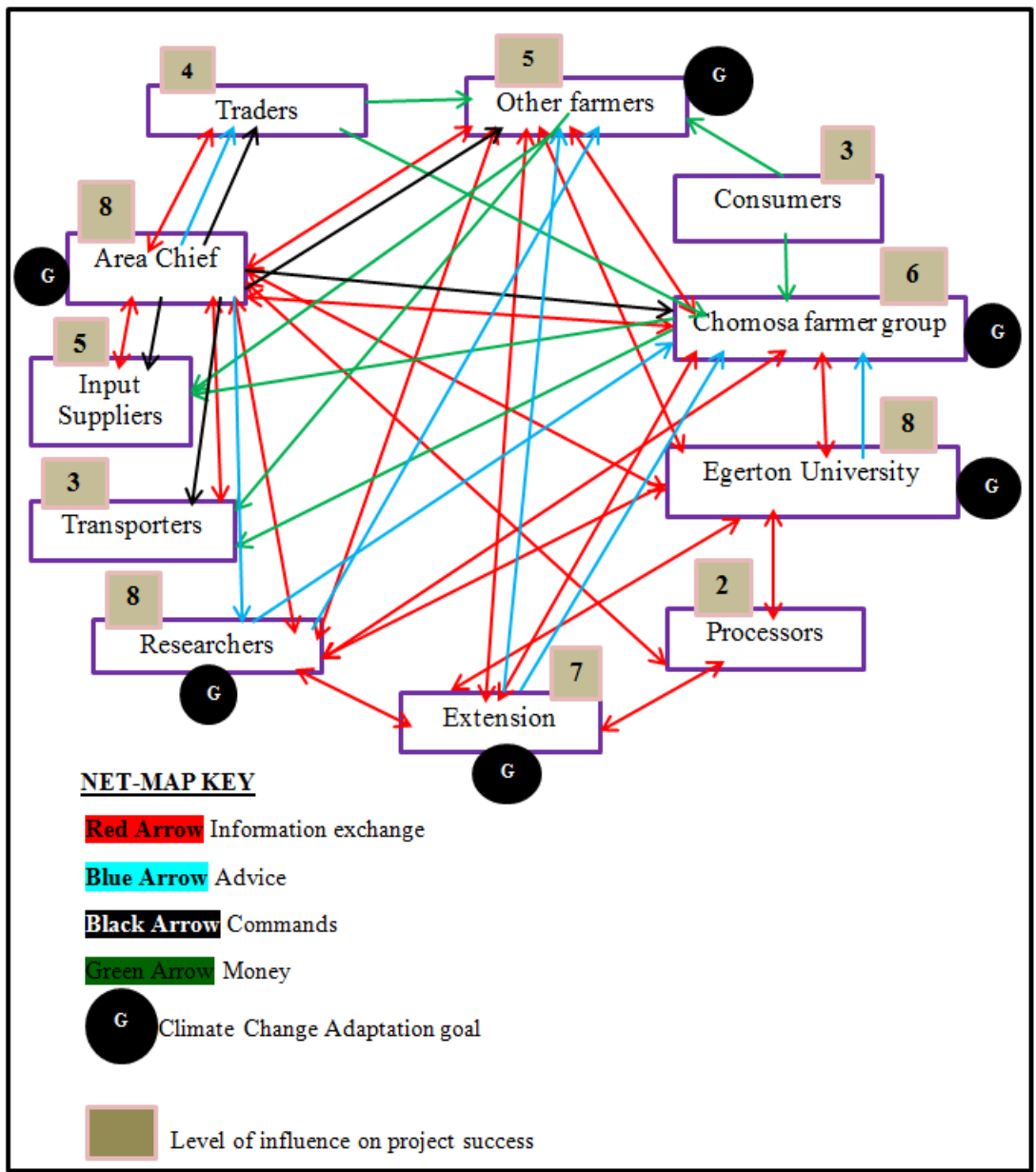

Figure 3. Digital Net-Map of stakeholder linkages in Mauche 
Based on the Net-Map findings, it became clear that:

The climate change adaptation goal spearheaded by Egerton University and KALRO had overwhelming support from the local administration, extension service providers and farmers. The private sector notably traders, transporters and processors did not demonstrate much contribution towards the goal; neither did they have much influence on the success of the project. There emerged an opportunity for these private sector players to be more responsive in supporting climate change adaptation initiatives because they stood to gain more from higher productivity resulting from climate change adaptation.

There was no linkage between farmers and processors. The Njoro Canning Factory representative consequently invited officials of the CLC for a discussion with the factory management with a view of signing a contract to enable farmers supply potatoes and other produce such as garden peas, beans and chilies to the factory. He informed the participants that the factory preferred Tigoni variety for potato chips due to its good freezing qualities. However, other varieties could be used to make potato cubes, githeri (maize and beans mixture) and mixed vegetables.

Traders had a lot of influence in dictating potato prices. Lack of collective action in potato marketing by farmer groups and a court injunction on the $50 \mathrm{~kg}$ packaging legislation by potato cartels in Nakuru County had led to continued exploitation of farmers. It therefore came out clearly that good governance in potato marketing required farmers to engage in contract farming as well as group marketing.

The area Chief commanded a lot of power and influence. He mainly provided security, advice and enforced law and order within the community. Based on this finding, the Chief was coopted into the CLC committee in order to tap into his influence to assist in mobilizing farmer groups in his area for collective action in potato marketing through formation of Chomosa Farmers' Cooperative Society.

\subsection{Capacity Building Activities Carried out by the CLC}

The following activities were carried out by the CLC during the research period:

\subsubsection{Selection of Climate Change Adaptation Strategies}

A CLC meeting was held at KALRO Njoro to select climate change adaptation strategies from the options being tested at the mother trial (Plate 2).

The CLC members visited the Mother trial site to appreciate the effects of each treatment on the performance of potato (Plate 3). This involved observation of the crop stand, pests and disease incidence and counting of the tubers (Plate 4), which would later form part of the selection criteria in addition to cost effectiveness.

\subsubsection{Farmer Trainings}

A total of 6 farmer trainings were carried out as follows:
In collaboration with the International Potato Centre (CIP), 4 trainings were done on potato production, diseases and disease control and post-harvest management. One Training of Trainer (TOT) seminar was held at KALRO Njoro for 15 selected farmer representatives. The TOTs later carried out 3 trainings for 90 farmers with backstopping from SMACC and CIP. Selection of the farmer TOTs did not target Chomosa farmer group. It also involved representatives of two other potato farmer groups (Kaplelach Youth Group and Ogiilgei Farmer Group), for purposes of knowledge dissemination. Training of other farmers by the farmer TOTs involved both theory and practical on the potato farms. This proved to be very effective especially for some of the farmers who could neither read nor write. It also provided an opportunity for the farmers to identify potato pests and diseases and prescribe control measures. Plate 5 represents one of the trainings by the farmer TOTs.

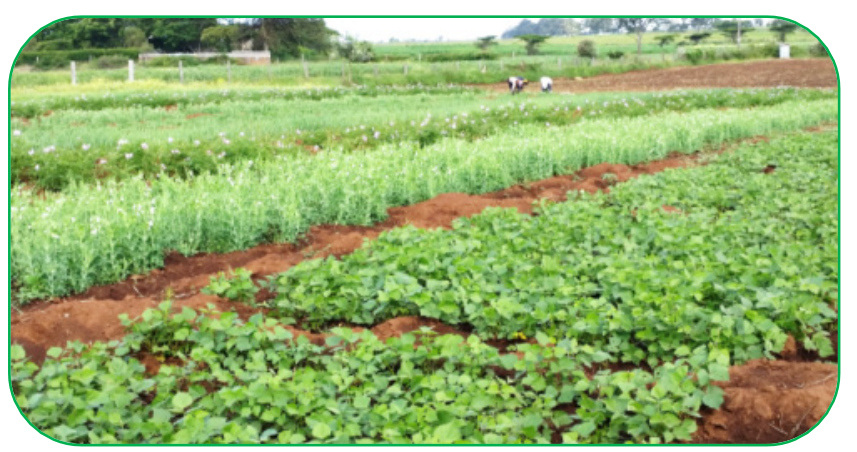

Plate 2. The Mother Trial site at KALRO Njoro

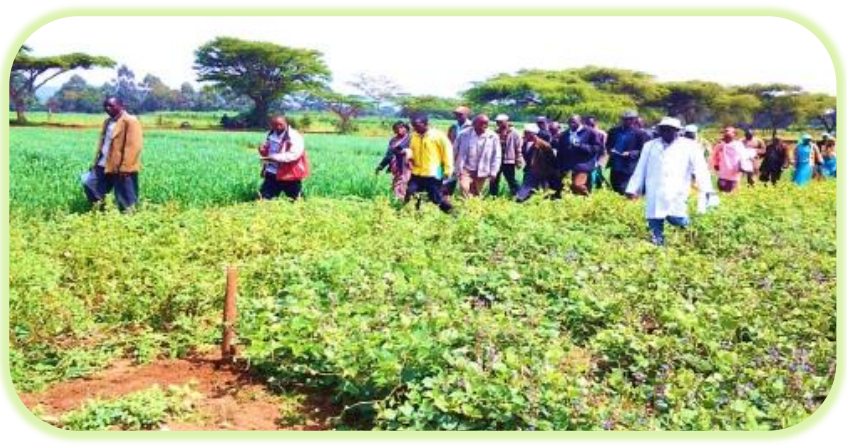

Plate 3. Viewing of the Mother Trial plots by the CLC

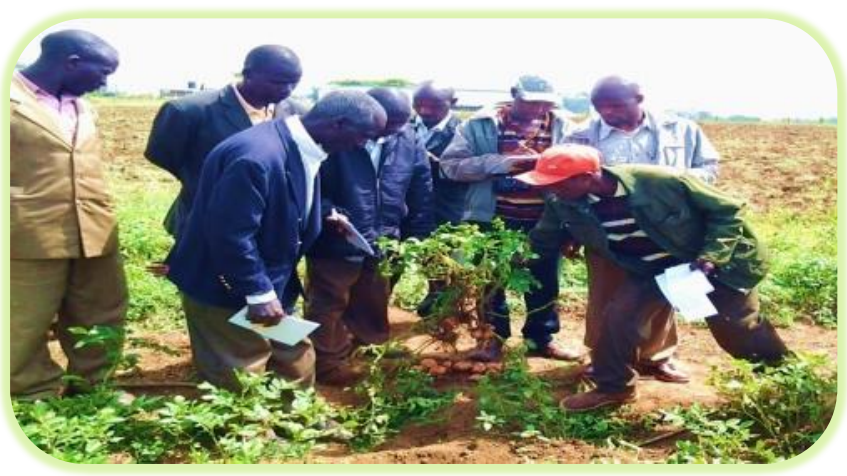

Plate 4. Analysis of potato performance according to each treatment 
A training on positive and negative selection of potato seed targeting 30 farmers was carried out. The training enabled the implementing farmer group to produce clean potato seed. Positive selection was done initially to select the best tubers to be used as seed. Subsequently negative selection was done to remove the diseased crops from the field and maintain clean tubers for selection as seed. The seed bears diseases to watch out for included bacterial wilt, late blight and viral infections.

\subsubsection{Field Visits}

Twelve field visits were carried out to monitor household adoption of CC adaptation technologies (Plate 5). This was necessary to asses if the demonstration in the baby trial plots were making any impact. Households were also monitored with regard to post harvest handling of the potato, acceptability of the potato as a major food item, water harvesting techniques and energy sources. It became clear farmers had adopted some of the recommendations from the baby trials.

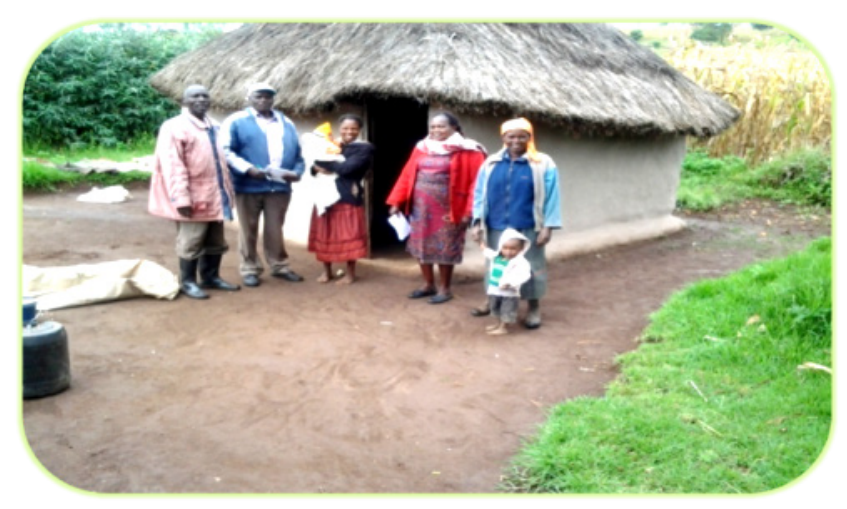

Plate 5. A visit to a homestead at Kaplelach village in Mauche

\subsubsection{Other CLC Activities}

These included a farmers' field day (Plate 6) and a tour to Elgeiyo-Marakwet County which enabled the CLC to appreciate collective marketing of potato through an active marketing association in the County. The farmers also learnt about e-marketing of potato through an Anglican Church supported farmer ICT Centre. Farmers also visited a potato cold storage facility made of charcoal and grass with a capacity of 3000 bags. This visit motivated the CLC committee members to initiate a process of uniting farmer groups for collective marketing of potato in Mauche.

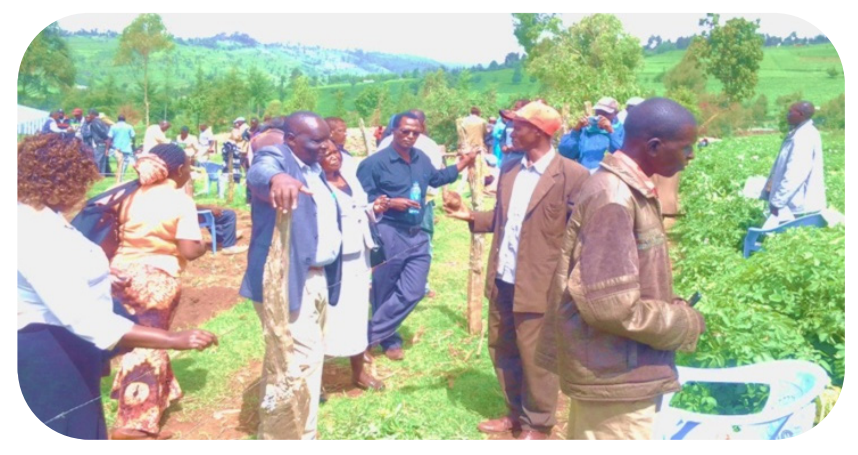

Plate 6. A farmer field day in Mauche

\subsection{Multi-criteria Analysis to Select Climate Change Adaptation Strategies}

A CLC meeting was held at KALRO Njoro mother trial site to select climate change adaptation strategies for implementation in the baby trial plots at Mauche. Multi criteria analysis (MCA) was employed to categorize and rank the options to be applied in CC adaptation. As suggested by Bartolini \&Viagi [15], MCA compares alternatives on the basis of more than one criterion. An action or an alternative is preferred if its expected utility is higher than expected utility of the alternatives to which it is compared.

The available $\mathrm{CC}$ adaptation options were crop production, water management and soil fertility intensification strategies which included:

i). Crop rotation - rotating potato with a legume - dolichos lablab

ii). Intercropping with garden pea

iii). Water harvesting by use of tied ridges

iv). Water harvesting using normal ridges

v). Soil fertility management by use of farm yard manure

vi). Use of green manure in the form of Leucaena triandra biomass.

In order to be able to compare the performance of various $\mathrm{CC}$ adaptation strategies, each strategy was given a score of 1-10 against established selection criteria. These criteria included crop stand (foliage), disease incidence, potato yield and cost effectiveness of the technology. Each criterion was given a weight that reflected the preferences of the CLC and the weighted sum of the different criteria was used to rank promising and feasible adaptation options. The ranking of $\mathrm{CC}$ adaptation strategies based on MCA is presented in Table 2.

Table 2. Performance matrix of climate change adaptation options

\begin{tabular}{|c|c|c|c|c|c|c|}
\hline $\mathrm{CC}$ adaptation strategy & $\begin{array}{l}\text { Crop Stand } \\
\quad(w t=2)\end{array}$ & $\begin{array}{l}\text { Disease incidence } \\
\quad(w t=3)\end{array}$ & $\begin{array}{l}\text { Potato Yield } \\
\quad(w t=3)\end{array}$ & $\begin{array}{c}\text { Cost effectiveness of } \\
\text { the Technology } \\
(w t=2)\end{array}$ & $\begin{array}{l}\text { Overall } \\
\text { Score }\end{array}$ & Rank \\
\hline Crop rotation & 7 & 8 & 7 & 8 & 7.5 & 1 \\
\hline Intercropping & 6 & 7 & 6 & 7 & 6.5 & 4 \\
\hline Water harvesting using Tied Ridges & 8 & 7 & 8 & 6 & 7.3 & 2 \\
\hline Water harvesting using Normal Ridges & 7 & 6 & 7 & 6 & 6.5 & 4 \\
\hline Use of Farm Yard Manure & 7 & 6 & 7 & 7 & 6.7 & 3 \\
\hline Use of Green Manure & 5 & 6 & 5 & 7 & 5.7 & 5 \\
\hline
\end{tabular}


Crop rotation (score $=7.5$ ) and water harvesting using Tied Ridges (score $=7.3$ ) were the most preferred options followed by use of Farm Yard Manure (Score $=6.7$ ). Intercropping and water harvesting using Normal Ridges (score $=6.5$ ) ranked fourth while the least preferred was Use of green manure in the form of Leucaena triandra biomass (score 5.7).

\subsection{Integration of Selected Climate Change Adaptation Strategies at the Baby Trial Plots}

The CLC identified three sites for the experimental plots (baby trials) at three different localities at Mauche Kaplelach, Ewaat and Mosop. Each experimental plot was one acre. SMACC project provided inputs for half an acre for three seasons while Chomosa the implementing farmer group provided inputs for the adjacent half an acre group plot in each site. The CLC participated in marking, land preparation, planting and management of the plots and observed the process of data collection by scientists from KALRO Njoro. The farmers had a hands-on experience in the research process as the scientists also benefited from the practical experiences of the farmers and incorporated local knowledge in the management of the experimental plots. The baby trial plots acted as learning centres for farmers to access climate change adaptation strategies. Plate 7 illustrates farmer participation in marking the baby trial plots.

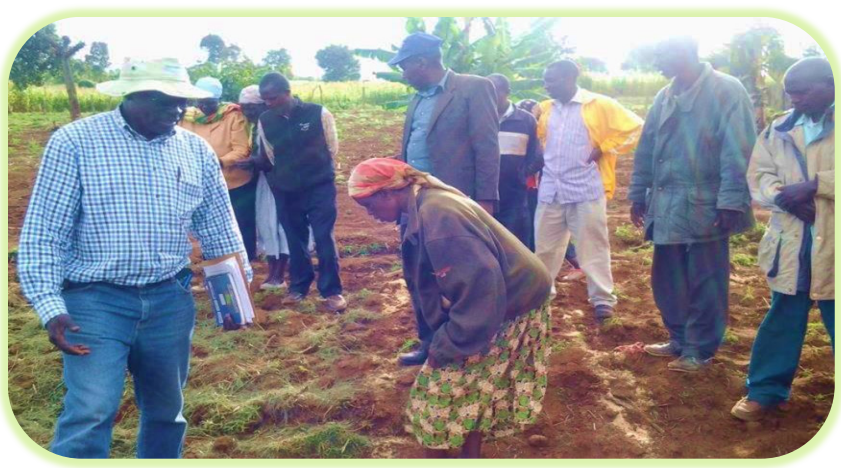

Plate 7. Farmers participate in marking the baby trial plots

\subsection{Assessment of Climate Change Adaptation at Household Level}

The farmers transferred the knowledge they gained from the experimental plots directly to their group farm and the positive change in performance of their crop was significant. The farmers further adopted the technologies in their own farms. Semi-structured interviews and two focus group discussions were carried out with the innovating farmers to assess their climate change adaptation practices at household level. Plate 8 illustrates a Focus Group Discussion in session.

The following thematic areas emerged during the interviews and FGDs are presented hereunder:

\subsubsection{Crop Production Intensification Strategies}

Crop rotation was the most adopted strategy due to the ease of its adoption. Many farmers initially rotated potato and maize which was detrimental to the soil as both crops are heavy miners of the soil. However with SMACC intervention, farmers have the knowledge and rotate potato or maize with beans or garden pea. Positive results were being achieved as illustrated in Plate 9 .

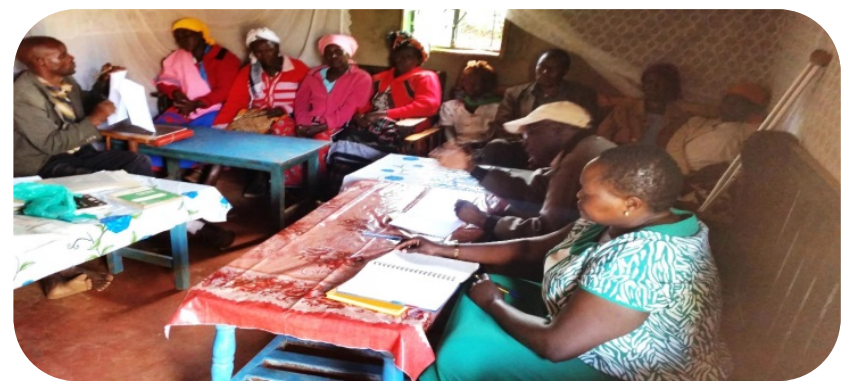

Plate 8. A focus group discussion with farmers

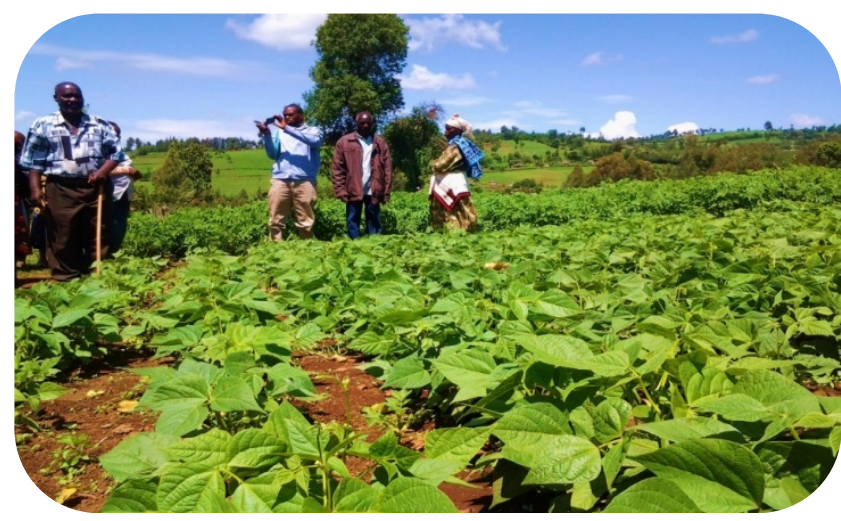

Plate 9. A farmer's pure stand bean on previous potato plot

\subsubsection{Water Management Intensification Strategies}

Use of tied ridges has proved to be very effective in water conservation and soil erosion management. One farmer displayed a portion of her farm that used to be washed off whenever there was run-off during heavy rains. Due to tied ridging the part of the farm became highly productive. Tied ridging is very effective in Mauche to contrast the sloping terrain in most areas. Plate 10 demonstrates the effectiveness of tied ridging in water management intensification.

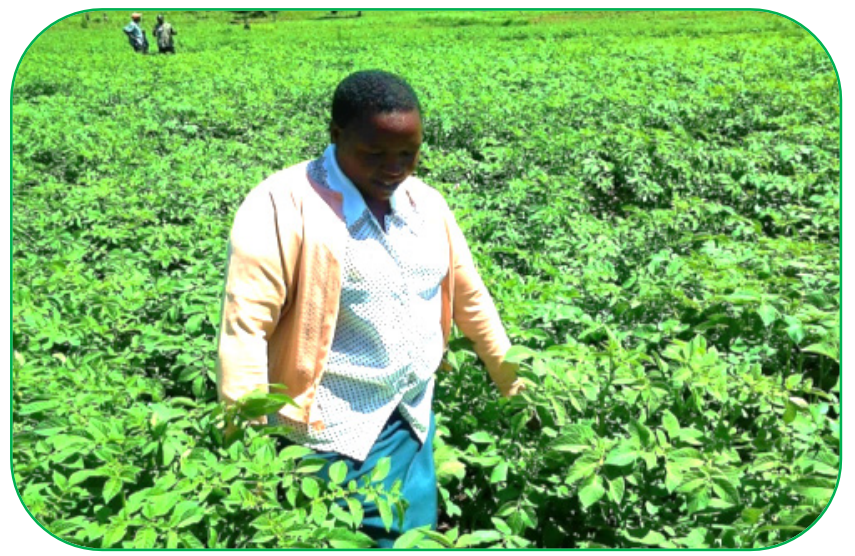

Plate 10. A farmer's healthy potato crop due to tied ridging 


\subsubsection{Soil Fertility Management Strategies}

Use of farm yard manure was popular due to its availability in Mauche where every household has livestock. The farmers expressed the need for training in compost making which is a good complement for farm yard manure. Green manure in the form of leucaena triandra and dolychos lablab was not popular due to low availability.

\subsubsection{Water Harvesting}

Water harvesting was an area of focus particularly in Mauche which is a high rainfall zone. The project promoted water harvesting as a climate change adaptation measure, both for domestic use, livestock consumption and irrigation of kitchen gardens particularly during the dry season when vegetables fetch good prices. The aim was to ensure household food security as well as household income. During the intervention period, some farmers made an effort to harvest some water for domestic use. This was achieved hrough rehabilitation of old dams (Plate 11a) or use of tanks for roof catchment (Plate 11b).

\subsection{Potato Marketing}

Potato traders move around in lorries with teams tasked with extending the bags and packaging the potatoes which are then loaded into lorries and transported to city markets or across the Kenyan borders to Tanzania and Uganda. The extended bag at Mauche goes for ksh 800 to 1500 depending on supply. One trader confided that the same bag sells at Ksh 2500 to 3000 in Nairobi but quickly justified that she had to meet the levies by traffic police on the road and packing charges for her lorry by the County Government of Nairobi. Plate 12a is extended potato bags ready to be being loaded into a lorry (Plate 12b).

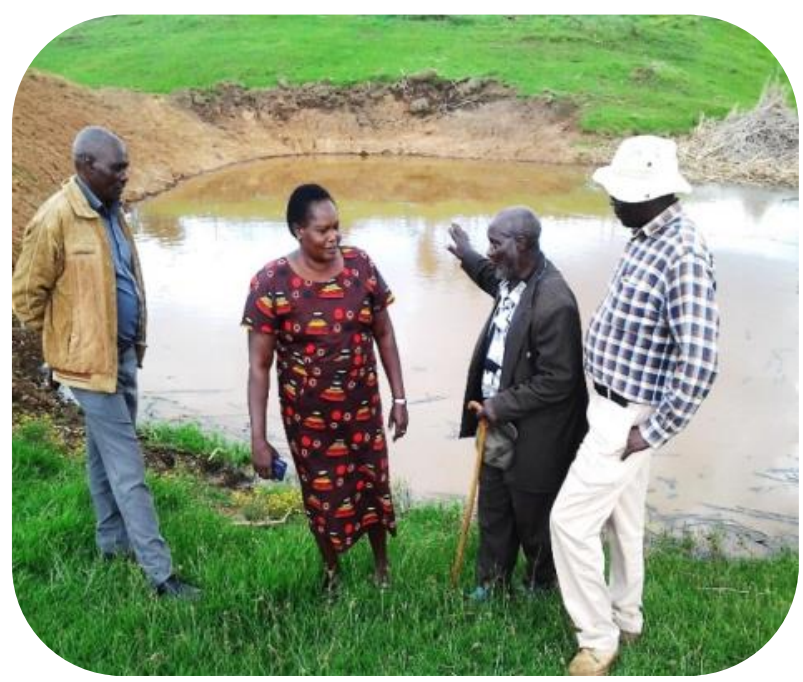

(a)

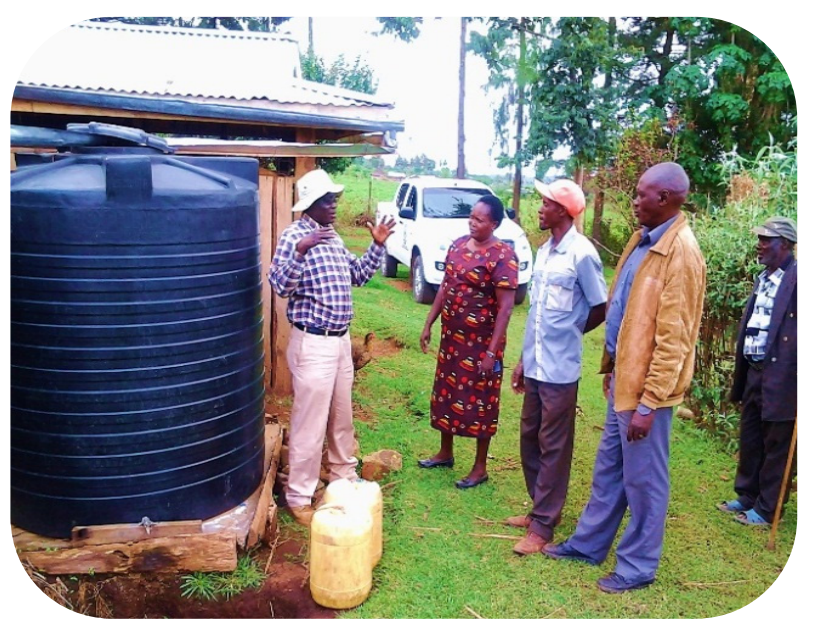

(b)

Plate 11. A rehabilitated dam (a) and roof catchment (b)

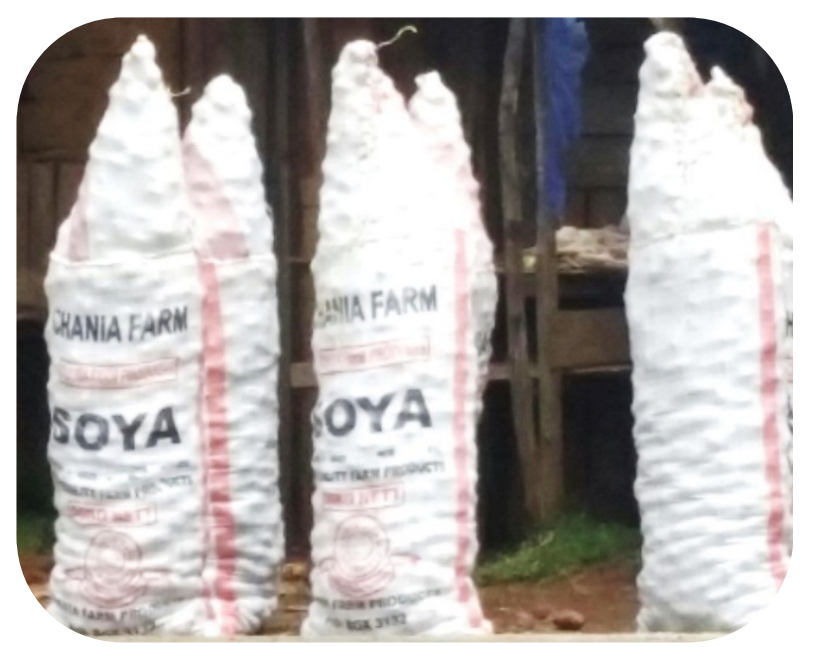

(a)

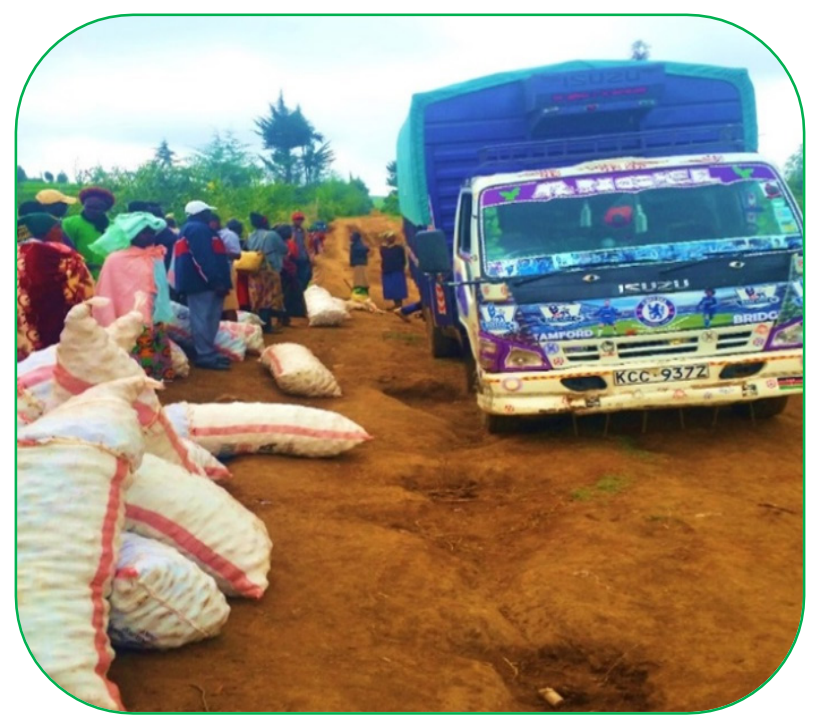

(b)

Plate 12. The $50 \mathrm{~kg}$ extended bag commonly known as Soya or Mkorino (a) ready to be loaded into a lorry (b) 


\subsection{Opportunities and Challenges of establishing a Collective Learning Community for Climate Change Adaptation}

Ensuring sustainability of the Collective Learning Community for climate change adaptation calls for evaluation of experiences and lessons learnt which in the long run will lead to redefinition of network goals and reframing network activities. Establishing the opportunities and challenges of establishing and maintaining a CLC for CC adaptation was achieved through continuous observation and documentation, which culminated in a CLC workshop in which the facilitators introduced the subject and divided the stakeholders into two groups. One group brainstormed on the opportunities while the other focused on the challenges. Each team later presented its outcomes at the plenary.

\section{a) Opportunities of establishing a Collective Learning Community for Climate Change Adaptation}

The CLC for CC adaptation brought in the following opportunities:

i). Enhanced stakeholder networking and collaboration

ii). CLC leadership

iii). Enhanced access to technologies

iv). Improved access to clean potato seed

v). Expanded access to potato market

\section{i) Enhanced stakeholder networking and collaboration}

The CLC enhanced formation of stakeholder networks to promote continuous interaction and communication among the members. Bringing all potato value chain stakeholders from the beginning of the research process created a forum to apply trans-disciplinarity. It ensured optimal knowledge integration, mutual learning processes, and the best conditions for dissemination, applying and adopting results in practice. It also enabled the stakeholders to identify failures in existing strategies to cope with climate change and develop strategies to address them. As noted by [8], climate change adaptation entails formation of information-sharing platforms that would enable different actors to come together and analyze shared constraints, promote dialogue, access new technologies, collaborate, engage in joint innovation and investment.

\section{ii) CLC leadership}

The leadership of the CLC was very important in creating linkages with sources of information and resources needed to run the CLC. A good leadership also inspired trust among CLC members and even motivated non- members to accept interventions championed by the CLC. By bringing potato stakeholders together, the CLC leadership enabled them focus on a common goal, hence avoiding duplication, competition and overlapping for efficient and effective allocation of resources. The CLC approach was intended to strengthen the ownership of project findings and secure a continuous use of project results.

\section{iii) Access to technologies}

The Mauche CLC enabled farmers to access CC adaptation potato value chain technologies from Egerton University, KALRO Njoro, CIP and the Nakuru County Department of Agriculture. These included soil, water and crop intensification strategies, post-harvest management, value addition, and water harvesting technologies. The Agricultural Technology Development Centre Nakuru provided $\mathrm{CC}$ adaptation fabricated tools. The farmers also accessed grain storage technology from the East African Grain Council.

\section{iv) Improved access to clean potato seed}

Capacity building by the CLC on positive selection to maintain clean potato seed, potato production and post-harvest management enabled Chomosa farmers to produce clean seed for their own use and sale to other farmers in Njoro Sub-County and neighbouring counties such as Baringo and Bomet. The clean potato seed initiative succeeded due to stakeholders co-funding of activities. Whereas SMACC project supported capacity building of farmers, the Department of Agriculture financed farm operations and purchase of certified seed through $\mathrm{Njaa}$ Marufuku programme. The group attained increase in potato yield from 40 bags per acre in 2013 to 105 bags per acre in 2015.

\section{v) Access to the Market}

The CLC initiated collective action for potato marketing in Mauche and Chomosa farmers started marketing their potatoes as a group. This enabled members to get better prices for their potatoes. While other farmers were selling the extended 50kg bag for Ksh 1300, Chomosa farmers sold non-extended $50 \mathrm{~kg}$ bag of clean potato seed for kshs 2500 . The group asset base grew from ksh 50,000 to more than one million in 2015.This was due to higher potato yields and better prices.

The CLC Advocated for collective action in potato marketing in Mauche, which required participation of all potato farmers including non-members of the CLC. Chomosa farmers' cooperative society was formed to facilitate potato marketing. Other farmer groups are being encouraged to join the cooperative society to facilitate group marketing of potato. The group has also purchased a plot in Mauche market at a cost of Kshs 300,000 which will house the cooperative society offices and a potato store.

\section{b) Challenges of Establishing and Maintaining a CLC for Climate Change Adaptation}

The challenges of establishing and maintaining a CLC included: i) Inconsistent participation of the private sector actors ii) Cost of maintaining the CLC iii) CLC ownership by actors

\section{i) Inconsistent participation of private sector actors}

The CLC network establishment and maintenance requires 
total commitment of relevant stakeholders for achievement of goals. However, inconsistent participation of the private sector value chain actors such as farm input suppliers, transporters and traders in CLC activities was evident. This was observed especially in farm related activities that they perceived as not benefiting them directly.There was overwhelming participation of input suppliers in activities such as field days which gave them an opportunity to sell their goods.

\section{ii) Cost of maintaining the CLC}

Maintaining a CLC platform can be expensive. There needs to be a budget for network maintenance and a definite and sustainable source of funding to organize group activities whereas platform members are expected to partly pay for their own expenses.

Fundraising from the stakeholders does not usually yield adequate financing. Some value chain actors may not be willing to contribute any finances if they do not see any economic benefit for them.

\section{iii) CLC ownership by actors}

It takes a while for the actors to internalize and own the platform, hence there needs to be a champion. Other than climate change adaptation, the Mauche CLC has the capacity to be instrumental in advocating for other community issues such as electricity connection, education, health, water and road network. In spite of these other functions, it has concentrated on its initial objective which was largely driven by SMACC project that acted as its Champion. The problem is that when the champion exits the CLC may not be sustained. A strategy needs to be developed for it to quickly reinvent itself to be relevant in addressing other issues affecting the community. Concerted effort has to be made to create local ownership and steering of the CLC. Recognition and support of the platform by the local leadership is important. Organizations that stand to benefit more from a cohesive CLC should use all means to ensure that the network remains strong and active.

\section{Conclusions and Recommendations}

1. A Collective Learning Community promotes integration of climate change adaptation strategies in potato production by facilitating farmers to access climate change adaptation technologies, clean potato seed and collective marketing of potato. Maintaining a Collective Learning Community requires shared goals, ownership and resources to facilitate planned activities. A CLC must be dynamic and vibrant in order to be relevant in addressing emerging issues in the society.

2. Capacity building in a Collective Learning Community is an important means for farmers to gain information on climate change adaptation technologies. This occurs when farmers interact with other stakeholders to network and innovate for knowledge generation.

3. The Collective Learning Community leadership should be developed based on dimensions of group dynamics, entrepreneurship, fund raising, lobbying and advocacy to ensure its effectiveness in spearheading climate change adaptation in smallholder farming.

4. Lack of collective action in potato marketing has rendered Mauche farmers vulnerable to exploitation by potato cartels operating in the area. The farmers do not have power to set prices in a system dominated by middlemen and cartels who take advantage of market information imperfections resulting in opportunistic behavior that suppresses potato farm gate prices. The price paid to potato farmers by brokers is insensitive to quality and provides no incentive to farmers to improve the quality of potato. Smallholder farmers need to form cooperatives and engage in contract farming in order to overcome technological and market constraints.

5. Collective marketing of farm produce and acquisition of inputs enable the farmers to negotiate prices in order to benefit from the economies of scale. Cooperatives facilitate bulking of farm produce for access to niche markets.

6. To bridge the existing deficit in certified potato seed, smallholder farmers should be capacity built on clean potato seed production techniques such as positive and negative selection. This would ensure timely access to clean potato seed by farmers at a more affordable price. Access to clean potato seed significantly controls spread of diseases thereby sustaining high potato yields, better household incomes and improved food security.

7. Any efforts to address climate change challenges in smallholder potato production must be complemented by investments in rural infrastructure such as market access roads, water dams and water pans to facilitate irrigation as well as storage facilities. This can be achieved through collaboration between the National Government, County Governments, partners and stakeholders

\section{Acknowledgements}

The authors acknowledge the financial support of Egerton University, Kenya; University of Natural Resources and Life Sciences, Austria and University of Hohenheim, Germany through Smallholder Farmer Strategies to Cope with Climate Change (SMACC) project.

\section{REFERENCES}

[1] Ospina, A. and Heeks, R. (2010). Linking ICTs and Climate Change Adaptation. University of Manchester, Manchester. 
[2] Kristjanson P., Neufeldt H., Gassner A., Mango J., Kyazze F.B., Desta S., Sayula G., Thiede B.,Förch W., Thornton P.K. and Coe R. (2012). Are food insecure smallholder households making changes in their farming practices? Evidence from East Africa. Springerlink.com.

[3] International Resources Group (2008). Impacts of Climate Change on Rural Livelihoods in Madagascar and the Potential for Adaptation- Quarterly Report. United States Agency for International Development (USAID), Washington DC.

[4] Government of Kenya (2010): Agricultural Sector Development Support Programme - Programme Document. Government Printer, Nairobi.

[5] Ojwang' G.O., Agatsiva J. and Situma C. (2010). Analysis of Climate Change and VariabilityRisks in the Smallholder Sector: Case Studies of the Laikipia and Narok Districts Representing Major Agro-ecological Zones in Kenya. FAO, Rome, Italy.

[6] Freyer B., Asch F., Birech R., Malinga J., Dessalegn Y. and Alemayehu G. (2012). Smallholder Farmer Strategies to cope with Climate Change (SMACC) proposal applied to ERA ARD II Net call 2012

[7] Lang D.J., Wiek A., Bergmann M., Stauffacher M., Martens P., Moll P. and Swilling M., Thomas C.J. (2012). Transdisciplinary research in sustainability science: practice, principles, and challenges. Springer

[8] International Potato Center (CIP). 2011. Roadmap for investment in the seed potato value chain in eastern Africa.
Lima, Peru, 27pp

[9] Scholz, R. (2012). The Global TRAPS Project: Transdisciplinary Processes for Sustainable Phosphorus Management (2010-2015). Internal paper, ETH Zurich.

[10] Nederlof, S., Wongtschowski M. and van der Lee F. (eds): 2011. Putting heads together. Agricultural innovation platforms in practice. Bulletin 396, KIT Publishers.

[11] Krasny M.E. and Lee S.K. (2002). Social learning as an approach to environmental education: Lessons from a program focusing on non-indigenous, invasive species. Environmental Education Research 8(2):101-119.

[12] Government of Kenya (2014). Ministry of Agriculture, Livestock Development and Fisheries: Annual Report for Mauche Ward - 2013/2014 Financial Year.

[13] Golder B. (2005). Cross Cutting Tool Stakeholder Analysis. Retrieved from

https://intranet.panda.org/documents/folder.cmf? U folder $\mathrm{ID}=60976$.

[14] Schiffer E. (2007). Net-Map Toolbox: Influence Mapping of Social Networks pp. 3-4. International Food Policy Research Institute. Presented at the Sunbelt Conference of the International Network of Social Network Analysis, 01-06 May 2007, Corfu, Greece.

[15] Bartolini F. and Viagi D. (2010). Recent Developments in Multi-Criteria Evaluation of Regulations. Presentation during the $2^{\text {nd }}$ MoniQA International Conference, Krakow, Poland, 8 June, 2010. 